Marquette University

e-Publications@Marquette

Biological Sciences Faculty Research and

Publications

Biological Sciences, Department of

$11-1-1968$

\title{
Electrophoretic Demonstration of the Hybrid Origin of the Gynogenetic Teleost Poecilia formosa
}

Peter Abramoff

Marquette University

Rezneat M. Darnell

Marquette University

Joseph Silvio Balsano

Marquette University

Published version. The American Naturalist, Vol. 102, No. 928 (November/December 1968): 555-558. Publisher Link. (C) 1968 University of Chicago Press. Used with permission. 


\title{
ELECTROPHORETIC DEMONSTRATION OF THE HYBRID ORIGIN OF THE GYNOGENETIC TELEOST POECILIA FORMOSA
}

\author{
Peter Abramoff, Rezneat M. Darnell, and Joseph S. Balsano \\ Department of Biology, Marquette University, Milwaukee, Wisconsin 53233
}

The all-female gynogenetic teleost Poecilia formosa is native to the streams and coastal lagoons of southern Texas and northeastern Mexico. In nature the species breeds with males of $P$. latipinna and $P$. mexicana in areas of sympatry (Hubbs and Hubbs, 1932; Darnell and Abramoff, 1968). Poecilia latipinna and $P$. mexicana are morphologically quite distinguishable, and $P$. formosa is intermediate between the two in respect to many morphological characters, such as certain scale counts, body proportions, and color patterns, as well as the size, shape, ray count, and position of the dorsal fin, etc. (Hubbs and Hubbs, 1932; Hubbs, Drewry, and Warburton, 1959; Menzel and Darnell, unpublished). On morphological, distributional, and reproductive grounds these authors suggested that the species $P$. formosa arose by hybridization between the two species with which it now breeds, a mode of speciation often postulated but never unequivocally demonstrated for vertebrates (Mayr, 1963). However, Uzzell and Goldblatt (1967) recently suggested that two species of Ambystoma may have arisen by hybridization.

In order to provide further insight into the characteristics of this unique species, an electrophoretic study of blood-plasma proteins was carried out on the presumed parental species and their laboratory-produced hybrids, as well as on $P$. formosa itself.

\section{MATERIAL AND METHODS}

Pregnant Poecilia latipinna and $P$. mexicana females collected in midJuly from Olmito, Texas, and Altamira, Tamaulipas, Mexico, respectively, produced laboratory broods the following week. As their sex became evident males were isolated to maintain virginity of the females.

When 2 months of age all males of both species had well-developed gonopodia, and reciprocal interspecific crosses (male $P$. latipinna $\times$ female $P$. mexicana, and vice versa) were established. Broods resulting from both crosses were born and reared to adult size, at which time the parents and 27 mature hybrid offspring were bled out. In addition, the individual plasmas from over 1,500 specimens of both parental types, and of $P$. formosa and other congeneric species previously collected from 33 localities throughout the area from Baton Rouge, Louisiana, to Progreso, Yucatan, were available for comparison and mixing experiments. 
Blood was collected in heparinized capillary tubes by cardiac puncture and the plasma removed by centrifugation at $1,200 \mathrm{rev} / \mathrm{min}$ and stored at $-20^{\circ} \mathrm{C}$ until needed. Individual plasma samples were subjected to electrophoresis in $\mathbf{7 . 5 \%}$ polyacrylamide gels according to the methods of Ornstein and Davis (1962) and Ornstein (1964). In preparation of the "small pore" solution of $7.5 \%$ polyacrylamide, the potassium ferricyanide was eliminated, and the amount of "temed" added was halved. The "large pore" solution "B" contained $25.6 \mathrm{ml} 1 \mathrm{-m}$ phosphoric acid, $5.7 \mathrm{~g}$ Tris, and water to $100 \mathrm{ml}(p \mathrm{H} 6.85-6.95)$. Ten microliters of fish plasma were mixed with $0.15 \mathrm{ml}$ of "large pore" gel, added to the top of the spacer gel, and then allowed to polymerize under fluorescent light for $15 \mathrm{~min}$. Simultaneous electrophoresis of 16 gels (one chicken serum standard plus 15 fish plasmas) was carried out for 90-115 min at $48 \mathrm{ma}(3 \mathrm{ma} /$ tube). Gels were stained after each experiment with amido black 10B, and destaining was accomplished in a modified starch destainer purchased from Otto Hiller (P.O. Box 1294, Madison, Wis.). The screened starch-gel holder was lined with coarse filter paper to prevent carbon particles from adhering to the gels. A comblike Plexiglas frame was placed in the holder to separate the gels in a prescribed order. Destaining was accomplished by placing the gel holder in the destainer containing sufficient glacial acetic acid to maintain a current of 3-6 amp across the gel (current supplied by a Schauer battery charger). Destaining was complete in 30-50 min. Gels were stored in sealed test tubes containing $7 \%$ acetic acid.

As shown in Figure 1, $P$. latipinna and $P$. mexicana are typically characterized by single albumin bands, whereas $P$. formosa always possesses two albumin bands of equal staining intensity. The electrophoretic mobilities of the two albumins in $P$. formosa correspond exactly to those of the two presumed parental species $P$. latipinna and $P$. mexicana, but not to any other congeneric species. This electrophoretic identity has further been demonstrated by mixing equal aliquots of plasma of $P$. latipinna or $P$. mexicana with $P$. formosa plasma prior to electrophoresis. Such mixing results in greater staining intensity in one or the other band depending on the species contributing the plasma mixed with that of $P$. formosa (Fig. 1). When the plasmas of other congeneric species are mixed with that of $P$. formosa, triple-albumin patterns, which indicate nonidentity in albumin electrophoretic mobilities, are obtained. Laboratory-produced hybrids of $P$. latipinna $\times P$. mexicana, like $P$. formosa, exhibit two albumin bands, and similar results are obtained when the plasmas of these hybrids are used in the mixing in place of the $P$. formosa. Furthermore, complete coincidence of the two albumins occurs when the plasma of a laboratory hybrid is mixed with that of $P$. formosa (Fig. 1).

\section{DISCUSSION}

It has been observed that female hybrids of Poecilia latipinna $\times P$. mexicana are morphologically indistinguishable from $P$. formosa (Hubbs and Hubbs, 1946), and it is now clear that they are also indistinguishable sero- 
logically. It might be argued that the morphological intermediacy of $P$. formosa could result from adaptation of an unrelated species to some intermediate habitat, but environmental factors are not likely to simultaneously induce such plasma coincidences as those observed. It might further be argued that $P$. formosa is itself a morphologically conservative, double-banded ancestral type from which the two single-banded species $P$. latipinna and $P$. mexicana have been derived. This possibility likewise seems remote, since double-albumin species are quite rare among vertebrate animals (Crenshaw, 1962; Johnson and Wicks, 1964; Cohen, 1965; Melartin and Blumberg, 1966) and since all other congeneric species examined to date ( $P$. latipinna, $P$. velifera, $P$. mexicana, $P$. sphenops, and $P$. latipunctata) possess only a single albumin band, except in certain areas of range overlap where hybridization is evident on morphological grounds. Furthermore, breeding experiments with several vertebrate species have shown that this double-albumin pattern can be obtained by the hybridization of two single-banded species or subspecies that have albumins with different electrophoretic mobilities (Beckman et al., 1962, 1963; Brandt et al., 1952). Thus, the arguments for convergence or ancestry by $P$. formosa are both untenable, and the conclusion of a hybrid origin for $P$. formosa is most clearly in line with present morphological and serological information. The two parental species $P$. latipinna and $P$. mexicana are sympatric in the lowland areas of eastern Mexico, and all three species may be taken in the same seine haul in the coastal lagoons of northeastern Mexico.

\section{SUMMARY}

Electrophoretic serum protein analysis reveals that the gynogenetic species Poecilia formosa possesses two albumin bands that are identical with those of laboratory-produced hybrids of its two sympatric species, $P$. latipinna and $P$. mexicana. The presumed parental species possess single albumins that are different in electrophoretic mobility. Studies involving the mixing of $P$. formosa, $P$. latipinna, P. mexicana, and the hybrid P. mexicana $\times P$. latipinna in various combinations demonstrate the electrophoretic identity of the two albumins of $P$. formosa with those of its presumed parental species. These results substantiate the conclusion, based on morphological and reproductive evidence, that $P$. formosa arose by hybridization of $P$. latipinna and $P$. mexicana.

\section{ACKNOWLEDGMENTS}

This study was supported by National Science Foundation grant GB 4712 to P. A. and R. M. D. and NSF Science Faculty Fellowship 65064 to J. S. B. We thank Robert R. Miller for critical review of the manuscript and Sally Stanton and Judith Black for technical assistance. 
1963. Serum protein variations in bird species and hybrids. Serol. Bull. 29:5-8.

Brandt, L. W., H. D. Smith, A. C. Andrews, and R. E. Clegg. 1952. Electrophoretic investigation of the serum proteins of certain birds and their hybrids. Arch. Biochem. Biophys. 36:11-17.

Cohen, B. L. 1965. Paucity of albumin variants in man. Nature 207:1109-1110.

Crenshaw, J. W. 1962. Variation in the serum albumins and other blood proteins of turtles of the Kinosternidae. Physiol. Zoöl. 35:157-165.

Darnell, R. M., and P. Abramoff. 1968. Distribution of the gynogenetic fish, Poecilia formosa, with remarks on the evolution of the species. Copeia 1968(2):354-361.

Hubbs, C., G. W. Drewry, and B. Warburton. 1959. Occurrence and morphology of a phenotypic male of a gynogenetic fish. Science 129:1227-1229.

Hubbs, C. L., and L. C. Hubbs. 1932. Apparent parthenogenesis in nature, in a form of fish of hybrid origin. Science 76:628-630.

- 1946. Experimental breeding of the Amazon molly. Aquarium J. 17:4-6.

Johnson, M. L., and M. Wicks. 1964. Serum-protein electrophoresis in mammals: significance in the higher taxonomic categories, p. 681-694. In C. A. Leone [ed.] Taxonomic biochemistry and serology. Ronald, New York.

Mayr, E. 1963. Animal species and evolution. Harvard Univ. Press, Cambridge, Mass.

Melartin, L., and B. S. Blumberg. 1966. Albumin Naskapi: a new variant of serum albumin. Science 153:1664-1666.

Ornstein, L. 1964. Disc electrophoresis-1. Background and theory. Ann. New York Acad. Sci. 121 (Art. 2) : 305-650.

Ornstein, L., and B. J. Davis. 1962. Disc electrophoresis. Distillation Products Industries, Rochester, N.Y.

Uzzell, T. M., Jr., and S. M. Goldblatt. 1967. Serum proteins of salamanders of the Ambystoma jeffersonianum complex, and the origin of the triploid species of the complex. Evolution 21:345-354.

Welser, C. F., H. J. Winkelmann, E. B. Cutler, and E. Barto. 1965. Albumin variations in the white-footed mouse, Peromyscus. Genetics 52:483. 


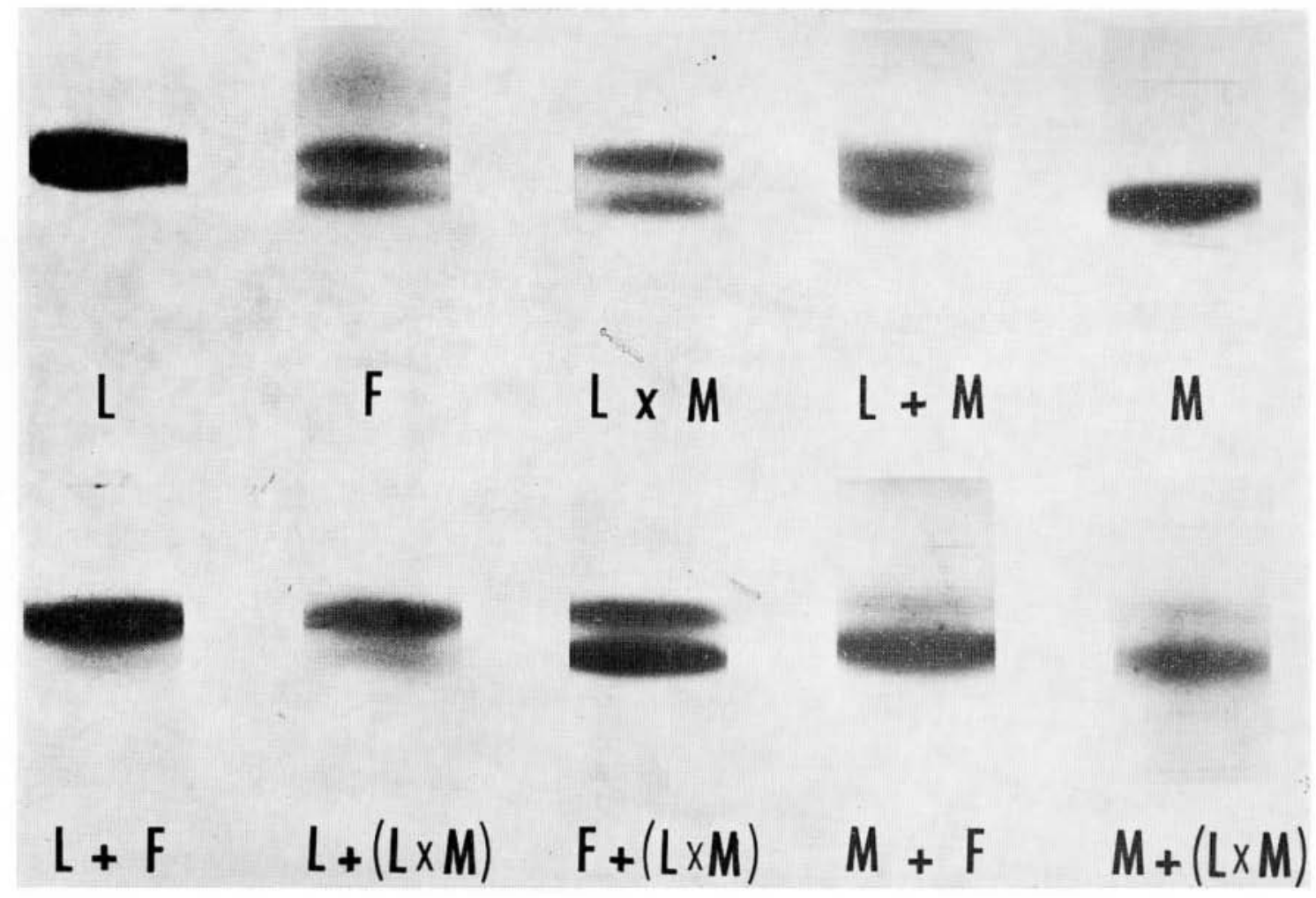

Fic. 1,-Acrylamide gel electrophoretic patterns showing albumin regions of plasmas of Poecilia species. Top row (left to right): Patterns for P. latipinna (L), P. formosa (F), hybrid of $P$. latipinna $\times P$. mexicana $(L \times M)$, mixtures of plasmas of $P$. latipinna and $P$. mexicana $(L+M)$, and plasma of P. mexicana $(M)$. Bottom row (left to right): Patterns for mixtures of the following plasmas: $P$. latipinna $(L)$ and $P$. formosa $(F), P$. latipinna $(L)$ and hybrid of $P$. latipinna $\times P$. mexicana $(L \times M), P$. formosa and hybrid $(L \times M), P$. mexicana $(M)$ and $P$. formosa $(F)$, and $P$. mexicana and hybrid $(L \times M)$. 